\title{
Time course of immune recovery and viral reactivation following hematopoietic stem cell transplantation
}

\author{
${ }^{1}$ Olga S. Pankratova, ${ }^{2}$ Alexei B. Chukhlovin \\ ${ }^{1}$ Tampere University Hospital, Tampere, Finland \\ ${ }^{2}$ R. Gorbacheva Memorial Research Institute of Children Oncology, Hematology and Transplantation, The St. Petersburg State I. Pavlov \\ Medical University
}

\section{Summary}

Total depletion of innate and adaptive immune cell populations occurs after intensive chemotherapy and hematopoietic stem cell transplantation (HSCT) then followed by gradual recovery of immune populations, due to progenitors derived from donor hematopoietic cells which differentiate to myeloid and lymphoid lineages. Time dynamics of immune reconstitution and differential maturation of distinct immune populations is only partially evaluated, especially, at early terms post-transplant. E.g., innate immunity is restored within 1st month after HSCT, due to rapid reconstitution of granulocytes, monocytes, and natural killer (NK) cells. Meanwhile, functional recovery of mature NK-cell subsets and blood monocytes may continue for up to 3 months.

Both T- and B-lymphocyte pools are restored much slower than myelomonocytic populations. The available information on their post-HSCT immune recovery is limited, since most studies are performed at later terms (>1 month post-transplant). Absolute numbers of CD8+ $\mathrm{T}$ cells return to control values ca. 4 months post-HSCT, however, exhibiting a skewed repertoire of memory $\mathrm{T}$ lymphocytes. Recovery and maturation rates of CD4+ $\mathrm{T}$ cells largely depend on residual thymus function, especially, in young subjects. Hence, a naïve CD4+ T cell population in pediatric patients predominates over 6 months post-HSCT. In older persons with inactive thymopoiesis the total CD4 cell counts remain low for years after HSCT. Meanwhile, antiviral cellular immunity is active since early terms post-transplant. E.g., cytotoxic
CD8+ cells specific for cytomegalovirus (CMV), or Epstein-Barr virus (EBV) rapidly expand in cases of CMV or EBV activation.

Despite recovery of absolute B-cell counts by day 30 post-HSCT, their functions, i.e., antigen-specific antibody production, are reduced for months and years after HSCT, due to slow restoration of mature immune cell populations, thus resemling normal evolution of B cell hierarchy in human organism.

Reactivation of herpesviruses (mostly, CMV, EBV and Herpes Simplex) is a known feature of immune deficiency. Timing of maximal herpesvirus incidence (2-3 months post-HSCT) corresponds to the period of CD8+ and CD4+ T cell functional deficiency and B cell immaturity, thus reflecting their suboptimal ability to eliminate herpesvirus-affected leukocytes. Individual terms of immune recovery after allo-HSCT depend on the patients' age, source of donor cells, acute GvHD post-HSCT etc. Vaccination response, being a potent in vivo criterion of immune recovery in post-transplant patients, is also dependent on the subjects' age and restored B cell functions. Time dynamics of specific antibody response shows that the patients with latent $\mathrm{CMV}$ reactivation may later exhibit a strong humoral immune response, thus making the infection self-limiting.

\section{Keywords}

Hematopoietic stem cell transplantation, immune reconstitution, differential maturation, time course, herpesvirus, reactivation. 


\section{Introduction}

Hematopoietic stem cell transplantation (HSCT) is usually preceded by intensive chemo- an/or radiation therapy causing cytotoxic insult to hematopoietic progenitors and lymphoid cell populations, depletion of myeloid and lymphoid cell pools, thus resulting into severe temporary immune deficiency. Therefore, HSCT patients are at high risk for bacterial and viral infections, at least, at early terms ( $<100$ days) post-transplant (Fig.1). The organ-specific bacterial and virus-associated complications following intensive chemoand/or radiotherapy are treated with antimicrobial and antiviral drugs, either in pre-emptive mode, or upon detection of the pathogens [6].

The aim of our review is to evaluate reconstitution terms and patterns for major immune populations following HSCT, comparing it with reactivation terms for the most common herpesviruses, i.e., cytomegalovirus (CMV), Epstein-Barr virus (EBV), and Herpes Simplex virus (HSV).

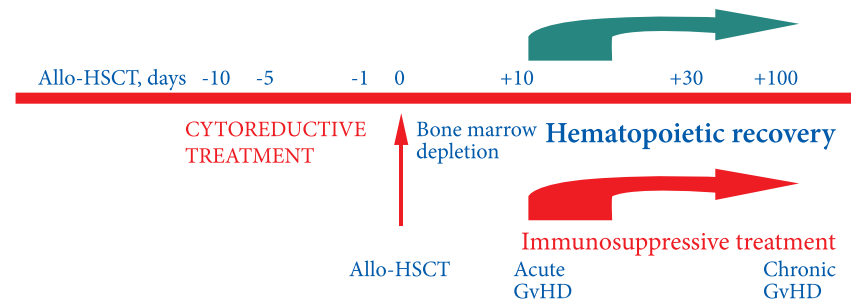

Reactivation of dormant herpesviruses Antiviral treatment (pre-emptive or optional)

Figure 1. Time course and main factors of viral reactivation/reinfection post-HSCT.

\section{Recovery of myeloid populations post-HSCT}

The granulocyte reconstitution depends on the so-called transit time, i.e., the total time period required for stem cell recruitment, differentiation, expansion, maturation and release to the bloodstream. Restoration terms for myeloid cells after hematopoietic stem cell transplantation (HSCT) are usually defined as the 1st day with neutrophil counts of $>0.5 \times 109 / \mathrm{L}$, with mean recovery terms of 12 to 20 days [1]. The time to neutrophil engraftment depends on the type of graft, with a median time of ca. 30 days for umbilical stem cells, 21 days for bone marrow, and 14 days for peripheral blood stem cells [44]. Generally, the innate immune system including granulocytes, monocytes, and NK cells recovers within weeks after intensive cytostatic treatment and HSCT.

According to Bemark et al. [4], granulocytes and monocytes (along with blood platelets), are the first mature donor cells appearing in peripheral blood post-transplant. These early-produced cells are generated by means of stress- (or ineffective) hemopoiesis, thus being functionally impaired. E.g., blood granulocytes produced up to day +30 post-HSCT are relatively fragile and apoptosis-prone [7]. The neutrophil functions (e.g. chemotaxis, phagocytosis and bacterial killing) may be also attenuated, whereas monocytes may produce normal, or, sometimes, decreased amounts of IL-1, IL-6 and TNF-1 [39, 42, 55]. Generally, innate immune response of phagocytic cells (granulocytes and monocytes) is, recovered within 4-6 weeks after engraftment of hematopoietic cells.

Absolute numbers of natural killer (NK) cells are normalized rather soon after HSCT. The study by Nguyen et al. [35] included ten cases of haplo-HSCT traced at d+14 to $\mathrm{d}+90$ post-transplant. In available cases No.8,9 and 10 , the percentages of NK cells were high since $d+14$, followed by reconstitution of B cells by $d+30$, whereas $T$ cells started to increase as late as at 3 months. The earliest reconstituted NK cells exhibit a CD56high phenotype, with high levels of NK G2A/CD94 and lower amounts of inhibitory KIR, thus reflecting their relative immaturity which may be traced up to 6 months post-HSCT $[35,51]$. A more extensive study was performed in 56 patients subjected to haplo-HSCT [51]. Blood samples were analyzed from day +15 to $>100$ days post-HSCT for CD56bright/dim like as CD117, NKG2A, CD62L and other surface differentiation markers. It has been shown that restoration of functionally mature, NK-cell subsets after haploidentical HSCT proceeds for, at least, 3 months. Hence, phenotypic maturation of NK cells and their functional ability post-transplant confirms suboptimal levels of mature NK's up to 3 months after HSCT [14].

Approximate terms of numeric and functional deficiencies for different blood leukocyte populations are summarized in Table.1.

Table 1. Differential timing of the post-HSCT recovery of distinct leukocyte populations in clinical settings

\begin{tabular}{|l|l|l|l|l|l|}
\hline $\begin{array}{l}\text { Blood leukocyte } \\
\text { populations }\end{array}$ & $\begin{array}{l}\text { Type of trans- } \\
\text { plants }\end{array}$ & Parameters tested & $\begin{array}{l}\text { Reaching } \\
\text { control } \\
\text { levels }\end{array}$ & $\begin{array}{l}\text { Factors affecting } \\
\text { recovery }\end{array}$ & Reference \\
\hline Granulocytes & Allogeneic & Granulocyte counts & 1 month & Type of transplant & [44] \\
\hline Granulocytes & Allogeneic & $\begin{array}{l}\text { Chemotaxis, phago- } \\
\text { cytosis, superoxide } \\
\text { production }\end{array}$ & $\begin{array}{l}\text { Up to } 9 \\
\text { months }\end{array}$ & $\begin{array}{l}\text { Severe aGvHD: } \\
\text { adverse effect }\end{array}$ & [55] \\
\hline
\end{tabular}




\begin{tabular}{|c|c|c|c|c|c|}
\hline $\begin{array}{l}\text { Blood leukocyte } \\
\text { populations }\end{array}$ & $\begin{array}{l}\text { Type of trans- } \\
\text { plants }\end{array}$ & Parameters tested & $\begin{array}{l}\text { Reaching } \\
\text { control } \\
\text { levels }\end{array}$ & $\begin{array}{l}\text { Factors affecting } \\
\text { recovery }\end{array}$ & Reference \\
\hline Granulocytes & Autologous & In vitro apoptosis & 1 month & NS & [7] \\
\hline Monocytes & $\begin{array}{l}\text { Allogeneic, pedi- } \\
\text { atric pats }\end{array}$ & $\begin{array}{l}\text { Decreased in vitro TNF } \\
\text { and IL-6 production }\end{array}$ & 3-4 weeks & $\begin{array}{l}\text { NS (not GvHD, CsA, } \\
\text { type of graft) }\end{array}$ & [39] \\
\hline Monocytes & Allogeneic & $\begin{array}{l}\text { Decreased in vitro IL-1 } \\
\text { production }\end{array}$ & 2 to $4 \mathrm{mo}$ & NS & [42] \\
\hline $\begin{array}{l}\text { Natural killer } \\
\text { cells }\end{array}$ & Haploidentical & Absolute numbers & 3 months & NS & [51] \\
\hline $\begin{array}{l}\text { Natural killer } \\
\text { cells }\end{array}$ & & Absolute numbers & 3 months & $\begin{array}{l}\text { Sooner rwith PBSC } \\
\text { grafts }\end{array}$ & [22] \\
\hline $\begin{array}{l}\text { Natural killer } \\
\text { cells }\end{array}$ & Haploidentical & $\begin{array}{l}\text { Maturity markers, } \\
\text { cytotoxicity }\end{array}$ & $>6$ months & NS & [35] \\
\hline $\begin{array}{l}\text { Natural killer } \\
\text { cells }\end{array}$ & Allogeneic & $\begin{array}{l}\text { Maturity markers } \\
\text { (CD56+ subsets) }\end{array}$ & $>3$ months & NS & [14] \\
\hline $\mathrm{T}$ cells & Autologous & Absolute numbers & 6 months & NS & [3] \\
\hline CD8+ T cells & Allogeneic & Absolute numbers & $\begin{array}{l}12-15 \\
\text { weeks }\end{array}$ & $\begin{array}{l}\text { Sooner with PBSC } \\
\text { grafts }\end{array}$ & [22] \\
\hline CD4+ T cells & Allogeneic & Absolute numbers & $\begin{array}{l}15 \text { weeks } \\
\text { and later }\end{array}$ & $\begin{array}{l}\text { Sooner with PBSC } \\
\text { grafts }\end{array}$ & [22] \\
\hline $\begin{array}{l}\text { CD4+ T cells, } \\
\text { naive }\end{array}$ & Autologous & Absolute numbers & $>10$ years & NS & [11] \\
\hline B cells & Autologous & Absolute numbers & 6 months & NS & [3] \\
\hline $\begin{array}{l}\text { Transitional } \\
\text { memory B cells } \\
\text { (CD27-, lgM+) }\end{array}$ & Allogeneic & Relative numbers & $>1$ year & $\begin{array}{l}\text { GvHD: adverse } \\
\text { effect }\end{array}$ & [4] \\
\hline $\begin{array}{l}\text { Memory B cells } \\
(\mathrm{CD} 27+)\end{array}$ & Allogeneic & $\begin{array}{l}\text { Relative } \\
\text { numbers }\end{array}$ & $>2$ years & Pediatric pats & [2] \\
\hline
\end{tabular}

NS, non specified

\section{Overview of T cell reconstitution post-HSCT}

Adaptive immunity after HSCT recovers much slower than innate immune response. E.g., B- and T-cell counts may normalize during the first months after transplantation [47]. A comprehensive summary of data concerning lymphocyte subpopulations following allo-HSCT is presented by de Koning et al. [12]. The authors state, however, that available information on the post-HSCT recovery of generic T, B and NK cells is limited by later terms ( $>1$ month post-transplant).

The numbers of CD8+ T cells post-transplant increase earlier than those of CD4+ T cells. Therefore, the CD4/CD8 ratio is initially reversed in these patients [15]. A sufficient number of $\mathrm{T}$ cell-related immune parameters were studied by [21] who evaluated immune recovery in 67 patients with acute myeloid leukemia (AML) following allo-HSCT. They studied $\mathrm{CD} 3+, \mathrm{CD} 3+\mathrm{CD} 4+, \mathrm{CD} 3+\mathrm{CD} 8+, \mathrm{CD} 3+\mathrm{CD} 4+/ \mathrm{CD} 3+\mathrm{CD} 8+$ ratio, CD3-CD56+, and CD19+ cells on days $+30 \ldots 365$. Peripheral blast counts $>5 \%$ were related to lower number of CD3+CD4+ (day +30) and NK cells (day +180; $\mathrm{p}=0.02)$. Intensity of conditioning did not have any significant impact on the kinetics of immune recovery. Patients with normal $\mathrm{CD} 3+\mathrm{CD} 4+/ \mathrm{CD} 3+\mathrm{CD} 8+$ ratio $($ day +30$)$ and NK cell counts (day +90; $\mathrm{p}<0.05)$ experienced better survival than those with decreased parameters. Post-transplant sepsis or severe infections were associated with impaired CD3+CD8+ (day +90; $\mathrm{p}=0.015)$ and CD19+ (day +90; $\mathrm{p}=0.02)$ recovery. Relapse in patients following allo-SCT showed an association with decreased numbers of CD19+ $($ day +270$)$ and NK cells (day +365). Acute GvHD (II-IV) was accompanied by reduced CD19+ and CD3+CD4+ cells. Thus, deficiencies of the major lymphoid populations correlated with common post-transplant complications. 
There are two biological pathways for restoration of CD4+ T cells in HSCT cases, i.e., thymus-dependent (central) and peripheral mechanisms, as discussed by Gress et al. [16]. In pediatric patients with chemotherapy-induced lymphopenia the recovery of naive, CD45RA+CD45RO- CD4+ T cells predominated within first six months, accompanied by marked increase of thymus volume [30]. These data again suggest the thymus-dependent $\mathrm{T}$ cell production to be primarily responsible for the repopulation of peripheral CD4+ T cells in young patients. Meanwhile, therapy-related lymphopenia in adults (ages over 30) was recovered by scarce production of CD45RA+ CD4+ cells during the first year post therapy. However, CD45RO+CD4+ cells increased rapidly in number, repopulating the $\mathrm{CD} 4+\mathrm{T}$ cells to pretreatment levels within the first 3 months after chemotherapy [17]. Thus, the "adult" type of CD4+ T cell recovery reflects a thymus-independent expansion pathway resulting into production of memory $\mathrm{T}$ cells. Therefore, in absence of effective thymopoiesis, the levels of total CD4 cells may remain low, even 4-5 years after transplant. Furthermore, thymus-dependent CD4 production caused renewal of central memory populations, identified as CD62L+ CCR7+ CD45RA- [18]. Hence, proper thymus functioning is necessary for rapid CD4+T cell restoration following HSCT. Therefore, pediatric patients have, potentially, more chances to restore their $\mathrm{T}$ cell pool within a shorter time period.

The immunological status of 37 adult patients with lymphoma after high-dose chemotherapy auto-SCT was studied by Dean et al. [11]. At a median follow-up of 10.5 years (range 2.2-20.2) following auto-SCT, the proportion of CD4(+) cells remained significantly reduced in patients compared with controls, predominantly a result of persistently reduced naive $\mathrm{CD} 4(+)$ cell numbers. The numbers of naive $\mathrm{CD} 8(+)$ lymphocytes $(\mathrm{P}=0.014)$ and transitional $\mathrm{B}$ cells $(\mathrm{P}=0.008)$ were also significantly reduced. Revaccination of the patients, as a test for antibody induction, showed ambiguous results. Hence, immunological deficiency of $\mathrm{T}$ cell subsets may be retained for many years after cytostatic treatment and auto-SCT.

In view of polyclonal $\mathrm{T}$ cell reconstitution post-HSCT, it, generally, may produce only minor fractions targeted for specific viral pathogens. Over last 10-15 years, a search for enrichment and expansion of virus-specific $\mathrm{T}$ cells (against CMV, EBV etc.) draws much attention. The CD8+T cell clones recognizing viruses are also present at the time of HSCT, being potentially able of selective expansion in cases of CMV or EBV activation. However, at the first months after transplantation, a narrow and skewed repertoire of $\mathrm{T}$ lymphocytes with memory-like phenotype is observed [5, 27]. Therefore, many groups have studied adoptive T-cell transfer, e.g., establishment of early virus-specific T cell populations as a means of immune recovery acceleration and prevention of early viral infections [50]. Moreover, deficiency of such T-cell clones with virus-restricted specificity may be a sufficient clinical factor at remote terms, e.g., effects of sustained Epstein-Barr virus (EBV) activation, causing the so-called secondary lymphoproliferative disease (LPD) in HSCT patients. Both short- and long-term immunotherapeutic strategies, including virus-specific $\mathrm{T}$ cells, are widely discussed.

\section{B cell recovery post-HSCT}

An extensive review by Bemark et al. [4] discussed time course and reasons for altered antibody response and B cell evolution following HSCT, in context of peripheral B cell differentiation. The mature B cells and their precursors are known to be efficiently depleted during conditioning, the levels of circulating IgG antibodies drop slowly, due to long half-life of IgG in serum and the survival of many plasma cells after myelodepletion $[46,52]$. Recipient plasma cells are lost relatively quickly post-HSCT, due to cytotoxicity of conditioning, or depletion of patients' plasma cells by donor-derived $\mathrm{T}$ cells. Moreover, memory B cells replenish the pool of plasma cells which produce specific antibodies induced by vaccinations. Hence the loss of specific antibodies may require revaccination several months after HSCT.

The B cells are deficient in peripheral blood over the first months after HSCT, with gradual normalization of cell counts within 6-12 months [3]. Memory B cells expressing CD27 did not expand to full scale, remaining at subnormal levels for, at least, 2 years after transplantation, as shown by Avanzini et al. [2] in pediatric HSCT patients. The profiles of circulating B cells were studied at 3 to 24 months post-transplant. At any terms, the patients displayed a significantly higher percentage of naive ( $\operatorname{IgD}+\mathrm{CD} 27-)$ B cells and showed significantly lower in vitro stimulation of Ig production, as compared to healthy controls. One should, however, consider an opportunity of donor memory B cell transfer, like as persistence of residual memory B cells early after HSCT, especially following reduced-intensity conditioning regimens.

Concerning mitogenic response of B cells from HSCT patients, a near-normal in vitro proliferation was shown after 8-day culturing with EBV particles, whereas response to pokeweed mitogen (PWM) was significantly decreased [29]. T cells from HSCT patients showed a decreased helper ability in PWM-induced B cell activation. Intrinsic deficiencies within the B cell compartment may inhibit their nonspecific mitogenic responses.

An alternative definition of human transitional memory $\mathrm{B}$ cells is that they are CD27 -IgM+ CD5- CD10-. These immature B cell subsets cells are abundant in young children and in cord blood, and constitute $25-50 \%$ of all B cells even 1 year after HSCT, thus depicting a long-term immaturity of B cell populations post-transplant [4].

Following HSCT, the cells producing different antibody subclasses emerge in a distinct order, with production of IgM antibodies within a few months, followed by IgG1/ IgG3, IgG2/IgG4 and finally IgA [13]. Thus, deficiencies of humoral immune response are common after HSCT, being lifelong in some cases, due to intrinsic defects in B cells as well as prolonged deficiency of T helpers (e.g., naïve CD4+ $\mathrm{T}$ cells) in peripheral blood. Follicular dendritic cells (FDC) in lymph nodes may be also damaged by cytotoxic chemotherapy thus impairing the production of T cell-dependent antibody responses with germinal centre reactions [4]. With respect to long-term clinical consequences, aside of chronic GVHD, one should consider a risk of recurrent bacterial 
infections and poor responses to polysaccharide vaccines in HSCT survivors.

Hence, long-term T- and B cell immune deficiencies in allo-transplanted patients, seem to be a regular condition caused by preceding cytostatic treatment, and long-lasting immunosuppressive treatment post-transplant. Gradual restoration of normal immune hierarchy may proceed for years in these cases, especially in adult and elderly patients, causing retarded recovery of the key antiviral cell populations (CD4+ lymphocytes, mature NK cells), as well as B cells, including those producing virus-specific antibodies.

\section{Vaccine-induced antibody response post-transplant}

It is well known that distinct lymphoid subpopulations recover at different rates post-HSCT, thus affecting humoral immune response. Specific antibody production upon vaccination is an integral index of immune response. Surprisingly, there are only sparsed data on immunization and antibody response in these patients, especially at early terms $(<6 \mathrm{mo})$ post-HSCT.

Generally, the post-vaccinal immunity in HSCT recipients is determined by the long-term antibody response which largely determines infectious safety for the children post-transplant. E.g., Inaba et al. [20] performed a study at the St. Jude Children's Hospital among 210 pediatric allo-HSCT recipients one year after transplantation. All the patients were re-immunized with combined vaccines, i.e., diphtheria-tetanus (Td), measles, mumps and rubella (MMR), as well as against hepatitis B and poliovirus at their first annual post-transplantation visit. The authors evaluated quality of routine immunization against eight common infections diphtheria, tetanus, pertussis, measles, mumps, rubella, hepatitis B, and poliovirus). Long-term antibody responses (>5 years post-vaccination) were seen for tetanus $(95.7 \%)$, rubella (92.3\%), poliovirus (97.9\%), and, in diphtheria-tetanus-acellular pertussis (DTaP) recipients, diphtheria (100\%), whereas pertussis vaccines were less effective (25\% of cases with protective antibody levels).

In particular, testing for measles antibodies $(n=130)$ showed an increase of seropositivity rates from $30 \%$ to $67 \%$. This response to vaccine retained for $>5$ years. Lower CD3 counts were significantly associated with negative titres.

Results of influenza vaccination were reviewed by Ljungman and Avetisyan [24]. They discussed different works on the influenza vaccination in HSCT recipients. Appropriate studies on antibody response were rather small in size and difficult to compare, due to varying vaccination timing post-HSCT. Generally, the post-vaccinal response proved to be lower in HSCT patients as compared to healthy individuals, however, providing certain protection levels for the patients receiving influenza vaccine at $>6$ months or later after HSCT.

Of the 133 patients tested for rubella antibodies before immunization, $44 \%$ were positive. The percentage of patients positive for rubella antibodies more than doubled (93\%) within a year of vaccination, and this effect retained for more than 5 years. Among patients evaluated for hepatitis B surface antigen antibodies, 52\% were seropositive for before vaccination. Following immunization, $77 \%$ of the patients with antibody responses became $\mathrm{HBV}$-seropositive within 2 to 5 years. However, ca. $25 \%$ of the group did not develop detectable antibody response. The negative titers did correlate with lower CD4 counts and history of severe aGvHD.

Poliovirus type 1, 2, and 3 antibodies were found in 54-57\% of cases before immunization. Within years after immunization, the percentages of seropositive patients gradually increased, up to $98 \%$ of patients having protective titres at $>5$ years. Negative titres were associated, e.g., with older age at immunization, negative initial poliovirus serum titres, the use of radiation during the preconditioning therapy, and positive recipient status.

Hence, the vaccination failure in different cohorts was associated with following factors: older age and negative titres at immunization; lower CD3, CD4 or CD19 counts; higher IgM concentrations; positive recipient CMV serology; acute or chronic graft-versus-host disease; and radiation during preconditioning. These data are of great value for re-immunization strategies in this cohort at infectious risk.

A real opportunity of anti-HBV immunity transfer via donor cells is shown in a study by Lindemann et al [23]. The workers selected a group of patients/matched donor pairs without pre-existing HBV immunity. Twenty-seven prospective donors were vaccinated against HBV. The donor vaccination produced HBs antibodies specific cellular responses in most of them. Interestingly, since 2 weeks post-HSCT, 86 and $67 \%$ of the recipients had positive humoral and cellular HBV reactions. Subsequently, HBV immunity re-appeared in $83 \%$ of the recipients without revaccination. These results show that a transfer of specific humoral and cellular immunity by allogeneic hematopoietic cell transplantation (HSCT) should, in principle, be possible.

\section{Time course of latent virus activation in transplanted patients}

High occurence of CMV in HSCT patients mostly results from reactivation of a latent virus which is acquired since early childhood. Many patients become seropositive at the age of 3 to 5 years, showing appreciable levels of specific IgG antibodies in most HSC recipients, thus suggestive for a primary infection in past time [41]. Most authors guess that CMV reactivation in most cases is observed in CMV-positive patients, being a clearly negative factor for clinical outcomes [25, 43]. CMV-associated clinical conditions are known since many years, especially, pneumonias, hepatitis, colitis, cystitis [49].

Time-course of CMV reactivation/reinfection may be determined either as higher CMV genome copies in the sample (quantitative DNA real-time assay), or as increased incidence of PCR-positive tests in subsequent sample series. The 
mean incidence of CMV positivity in peripheral blood after HSCT reaches its peak values 2 to 3 months following intensive therapy and transplantation [31].

CMV incidence and reactivation rates depend on intensity of conditioning treatment (non-myeloablative versus myeloablative therapy). E.g., a study of $537 \mathrm{CMV}$-seropositive patients has shown that a non-myeloablative conditioning was associated with lesser risk of subsequent CMV infection at early terms posttransplant [34]. However, nonmyeloablative regimen (TBI+Fludarabine) was, generally, followed by retarded CMV reactivation, as compared to myeloablative treatment [19]. Interestingly, a supplementary immunosuppression, e.g., treatment with antithymocyte globulin, or total lymphoid irradiation, correlated with earlier CMV viremia post-transplant, if compared with standard myeloablative therapy [43].

In fact, selective in vivo depletion of T cells, e.g., treatment with antithymocyte globulin prior to haplo-HSCT may cause a sufficient delay in CD4+T cell recovery, along with higher rates of CMV reactivation, as compared to the regimen with posttransplant cyclophosphamide [48]. These results suggest that the treatments with faster recovery of CD4+ T cells seem to better preserve antiviral immunity, thus allowing more efficient handling with herpesvirus infection after haplo-HSCT. Hence, targeted suppression of lymphoid cell populations pre-transplant is likely to cause higher incidence of CMV reactivation after HSCT.

Of special interest is early CMV activation in CMV-seropositive patients transplanted form CMV-negative donors. Since renewal of hematopoiesis in allo-HSCT setting proceeds with donor cells, one may expect decreased levels of
anti-CMV specific $\mathrm{T}$ immunity, thus increasing risk of subsequent viremia [54].

In a similar HSCT cohort, we studied 143 patients with oncohematological disorders in a single-center study for herpesvirus reactivation post HSCT $[9,37]$. The patients were subject to allogeneic transplantation of hematopoietic stem cells (HSCT). Occurrence and dynamics of acute GvHD was registered in posttransplant period, as well as other complications (pneumonia, neurological disorders, mucositis, cystitis). Reactivation of HSV, CMV and EBV was detectable in blood leukocytes after HSCT, respectively, in 51\%, 57\% and $45 \%$ of all cases (2.3-2.5-fold more common that pre-transplant). Primary diagnosis, gender of patients and type of transplant did not significantly influence these ratios.

Meanwhile, frequencies of CMV and HSV detection were dependent on patients' age, with minimal detection rates at 1 to 4 years and a maximum at 10 to 20 years.

Prevalence of CMV positive tests was dependent upon the terms after HSCT, with a maximum at 2 nd and 3 rd months after transplantation (Fig.2A). As seen from previous data on cellular recovery, this time period is characterized by full restoration of innate immunity, and ongoing recovery maturation of adaptive lymphoid populations, e.g., CD4+ cells, and antibody-producing B cells. Similar post-transplant time dynamics was revealed for EBV reactivation (Fig 2B), thus presuming some analogies in reactivation mechanisms and type of interactions with host immune system. Herpes simplex (HSV) activation (Fig.2C) proceeded as soon as at 2nd3rd months after HSCT, probably, reflecting early affection of recipient epithelial cells, being its specific target population.
A

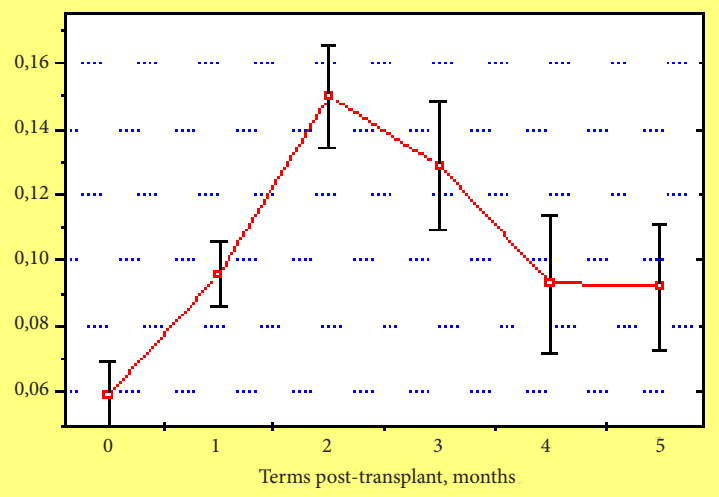

C

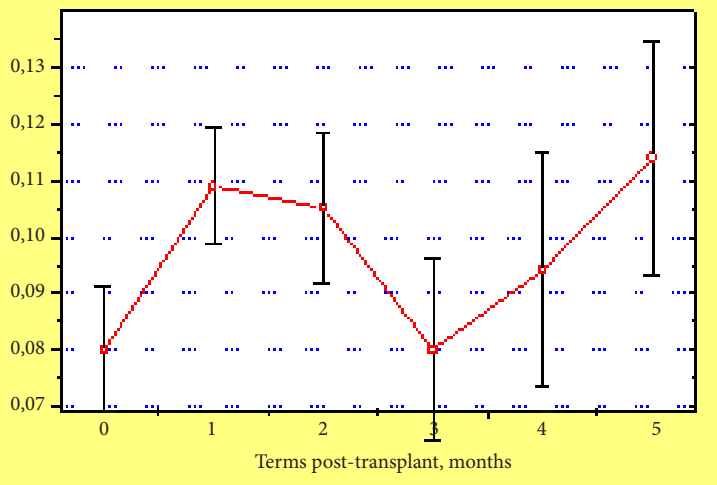

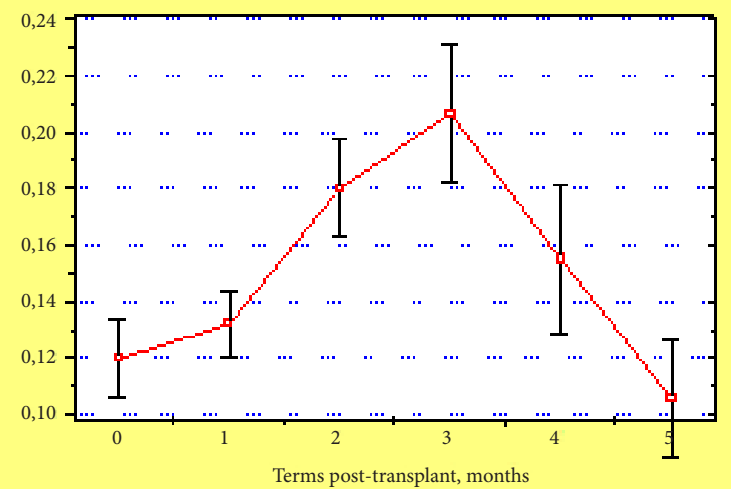

Figure 2. Time dependence of CMV (A), EBV (B) and HSV reactivation (PCR DNA in leukocytes) at different terms after hematopoietic stem cell transplantation ( $\mathrm{n}=198$ cases). Abscissa, Terms post-transplant, months. 0rdinate, frequency rates of CMV-positive tests (>1000 gene copies $/ \mathrm{mL}$ whole blood). 
Finally, the incidence of post-transplant viremia depended on the patient's age (Fig.3). I.e., in children of $<4$ years old, the post-HSCT reactivation of cytomegalovirus was not frequent, being significantly increased $(\mathrm{P}<0.02)$ in older children (5 to 15 years old) post-transplant. Incidence of HSV reactivation was also maximal in adolescent recipients (Fig.4). These findings may be explained by lower infection levels in youngest children, maximal infection frequency in adolescents (6 to 15 years old), and sufficient antiviral immune response in older patients.

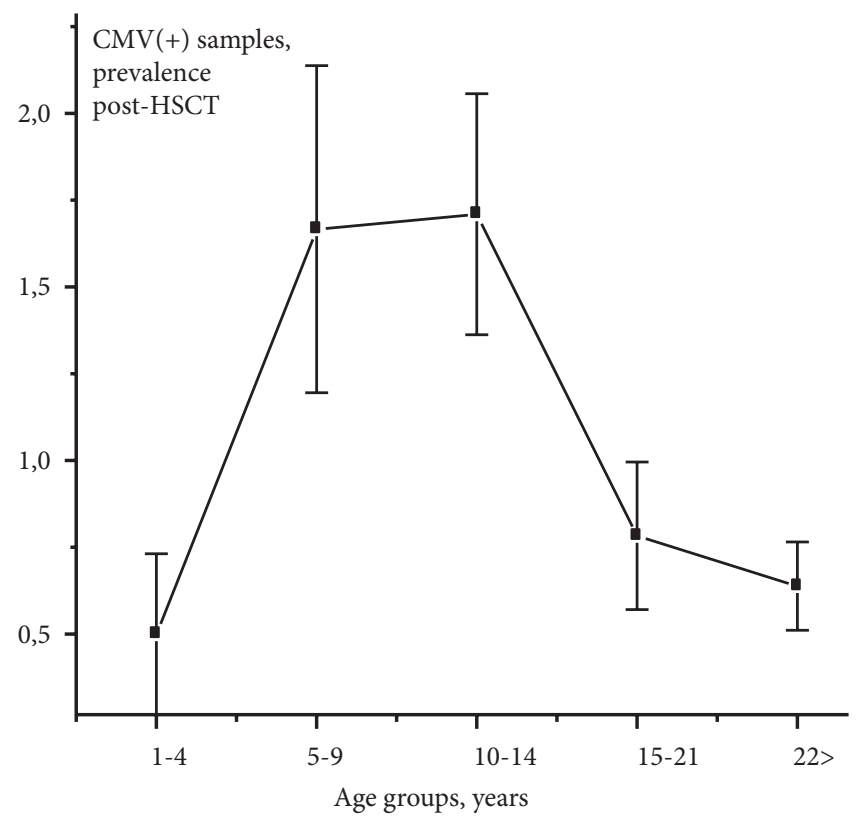

Figure. 3. Age dependence of CMV reactivation in total group of patients post-HSCT $(\mathrm{P}<0.01)$. Ordinate, number of positive samples per patient $(\mathrm{M}+\mathrm{m})$.

Along with studies of latent herpesviruses, some attention is now drawn to post-transplant reactivation of polyomaviruses (especially, BK and JC). E.g., BK virus is commonly found in urinary cell sediments by PCR approach, but it more frequently detected at 2-3 months post-HSCT [8]. Similar increase was observed for JC virus. Meanwhile, the BK and JC positivity in whole blood was not increased after HSCT, thus presuming only local reactivation of these viral pathogens.

\section{Antibody response to cytomegalo- virus reactivation}

Since 1980s, it was proposed that both passive humoral immunity and specific $\mathrm{T}$ cell-mediated response contribute to the protective effect against CMV infection in allo-HSCT patients. Relative role of serological and cytotoxic immune responses in CMV infection was studied by Ludwig et al. (2006) who compared levels of glycoprotein B (gB)-specific antibodies and CMV-specific IFN-gamma producing CD4+ cells in CMV-positive SCT patients with/without CMV reactivation after SCT. The recipients without CMV reactivation showed a slow but steady increase in both parameters after
Like as recovery of immune populations, the CMV reactivation after HSCT may depend on a number of similar biological factors: 1) age of the patient; 3 ) intensity of conditioning regimen. Seropositivity of recipient is considered a special intrinsic factor for herpesvirus reactivation. All these factors should be taken into account when predicting risk for clinical CMV infection after intensive cytostatic treatment.

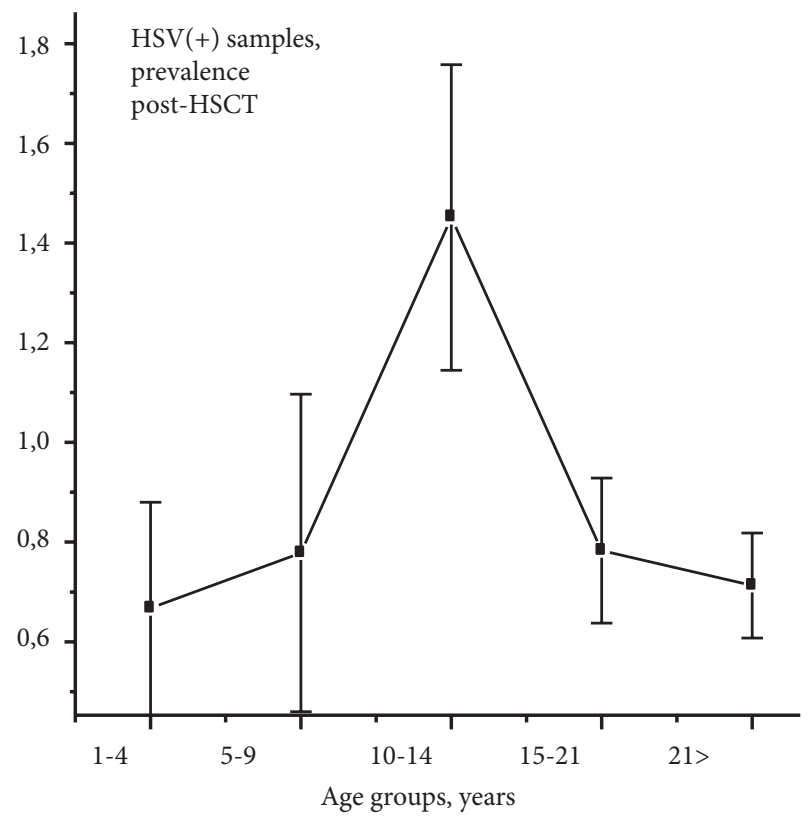

Figure. 4. Age dependence of HSV reactivation reactivation in total group of patients post-HSCT $(P<0.01)$. $0 r-$ dinate, number of positive samples per patient $M+m$ ).

SCT, indicating that initial high levels of gB specific antibodies or CMV specific CD4+ IFN-gamma+ cells are not necessary to prevent reactivation of CMV. Meanwhile, post-transplant CMV reactivation was associated with an increase in virus-specific CD4+ IFN-gamma+ cells prior to CMV activation, followed by a decline after the reactivation period. Patients who underwent only a single reactivation generated significant higher amounts of CD4+ IFN-gamma+ cells, than did patients with further reactivation episodes. Meanwhile, the course of $\mathrm{gB}$ specific antibodies for reactivating patients was something different, with significantly higher average values in the patients with CMV reactivation. This indicates that patients with a CMV reactivation exhibit a strong humoral dominated immune response.

Previous studies of protective anti-CMV antibodies in seropositive bone marrow recipients have shown induction of neutralizing anti-gB antibodies in cases of posttransplant CMV activation [40]. However, clinical significance of such neutralizing antibodies was not entirely confirmed in further studies [33]. The authors assessed time kinetics of the anti $\mathrm{gB}$ antibodies to $\mathrm{CMV}$ in 26 allo-HSC recipients. Neither absence, nor presence of CMV infection did correlate with serum concentrations of gB-specific and neutralizing anti- 
bodies. Recovery from CMV infection was not associated with antibody response to replication-associated antigens.

\section{Potential clinical complications of EBV reactivation in transplanted patients}

Among gamma-herpesviruses, the EBV is the mostly studied pathogen. Forty years ago, W and G. Henle had shown ability of EBV to infect B lymphocytes followed by their transformation to the lymphoblastoid virus-producing cells capable of long-term in vitro growth. Gamma-herpesviruses exhibit a well-known tropicity for lymphocytes, and, therefore, may induce lymphoproliferative disorders, as well as some muscular and endothelial neoplasias in humans [26]. The infected B-lymphoid cells reproduce normal stages of B cell differentiation in follicular germinal centers.

Latent EBV carriage is common to most adult subjects, as evidence by its common secretion with saliva. Uncontrolled proliferation of EBV-infected B cell in immunocompetent persons is blocked by cytotoxic lymphocytes. However, this mechanism of immune surveillance is largely failing in immunocompromised subjects $[10,36]$. Therefore, EBV reactivation after transplantation of solid organs and hematopoietic stem cells is often followed by secondary posttransplant lymphoproliferative disorders (PTLD). Typically, the PTLDs emerge after long-term and massive immunosuppressive therapy which results into decreased amounts and functions of EBV-specific cytotoxic T cells, along with uncontrolled, EBV-driven B cell proliferation [10]. The EBV-positive malignancies observed in solid organ transplants, mostly originate from the recipient B cells, whereas $90 \%$ of PTLD in HSCT patients develop from the donor B cells [45].

Tischer et al. [48] have shown that $1 / 4$ of patients pre-treated with ATG before HSCT developed PTLD, as compared to absence of this virally-induced condition among patients with presumably better preserved cytotoxic $\mathrm{T}$ cell populations.

\section{Conclusions}

Near-total depletion of innate and adaptive immune cell populations occurs due to intensive treatment followed by HSCT. Reconstitution of immune system from donor hematopoietic cells takes quite time periods needed for expansion, differentiation, migration and homing of granulocytes, monocytes, NK cells, T- and B cells. The intermediate maturation steps, especially, for lymphoid cell recovery, are known only to limited degree, and bear, mostly later terms (>1 month post-transplant).

Functional recovery of NK-cell subsets and blood monocytes may require up to 3 months; maturation and immune selection of CD8+ T cells proceeds for 3-4 months, whereas functional recovery of CD4+ $\mathrm{T}$ cells may be delayed for years, especially in older patients.
The B-cell ability to produce specific antibodies is partially retained, due to survival of resistant memory $B$ cells postHSCT, but differentiation and maturation of the donor-derived $\mathrm{B}$ cell hierarchy may require months and years.

Reactivation of herpesviruses in de novo produced donor cells, generally, proceeds in parallel with the periods of CD8+ and CD4+ T cell exhaustion, thus enabling expansion of latent herpesviruses, despite sufficient antibody response during CMV reactivation. Chronic EBV infection of B cells represents a more sufficient hazard, due to high risk of posttransplant lymphoproliferative disease at longer time range.

Hence, restoration of innate immunity, especially, monocytes/macrophages and NK cells originating from allografts, is most important at the early terms post-transplant, due to their immediate anti-infectious and GvL effects. At later terms ( $>100 \mathrm{~d}$ ), deficient reconstitution of CD4+T cells may be responsible for deleterious infections with viruses and fungi, with older patients being at higher risk. To date, the delayed recovery of lymphoid subsets, especially, virus-specific T cells and memory B cells represents a major limitation for the long-term clinical outcomes in allo-transplanted patients. Therefore, current studies are aiming for enforcement of virus-targeted T-cell therapy, in order to accelerate clearance of cells with activated virus from affected tissues [32].

\section{Conflict of interests}

No conflict of interests is declared.

\section{References}

1. Ali MY, Oyama Y, Monreal J, Winter J, Tallman M, Gordon LI, Williams S, Singhal S, Mehta J. Reassessing the definition of myeloid engraftment after autotransplantation: it is not necessary to see $0.5 \times 10(9) / 1$ neutrophils on 3 consecutive days to define myeloid recovery. Bone Marrow Transplant. 2002; 30 (11): 749-752.

2. Avanzini MA, Locatelli F, Dos Santos C, Maccario R, Lenta E, Oliveri M, Giebel S, De Stefano P, Rossi F, Giorgiani G, Amendola G, Telli S, Marconi M. B lymphocyte reconstitution after hematopoietic stem cell transplantation: functional immaturity and slow recovery of memory CD27+ B cells. Exp Hematol 2005; 33 (4): 480-486.

3. Baumgartner C, Morell A, Hirt A, Bucher U, Forster HK, Doran JE, Matter L, Brun del Re G, Wagner HP. Humoral immune function in pediatric patients treated with autologous bone marrow transplantation for B cell non-Hodgkin's lymphoma. The influence of ex vivo marrow decontamination with anti-Y 29/55 monoclonal antibody and complement. Blood. 1988;71(5):1211-1217.

4. Bemark M, Holmqvist J, Abrahamsson J, Mellgren K. Translational Mini-Review Series on B cell subsets in disease. Reconstitution after haematopoietic stem cell transplantation - revelation of B cell developmental pathways and lineage phenotypes. Clin Exp Immunol. 2012;167(1):15-25. 
5. Chalandon Y, Degermann S, Villard J, Arlettaz L, Kaiser L, Vischer S, Walter S, Heemskerk MH, van Lier RA, Helg C, Chapuis B, Roosnek E. Pre-transplantation CMV-specific $\mathrm{T}$ cells protect recipients of T-cell-depleted grafts against CMV-related complications. Blood 2006; 107:389-396.

6. Chemaly RF, Shah DP, Boeckh MJ. Management of respiratory viral infections in hematopoietic cell transplant recipients and patients with hematologic malignancies. Clin Infect Dis. 2014; 59 (Suppl 5): S344-S351.

7. Chukhlovin A. Enhanced ex vivo apoptosis of peripheral granulocytes is a sufficient factor of neutropenia following myeloablative chemotherapy. Leuk Res 2000; 24(6):507-509.

8. Chukhlovin AB, Eismont YuA, Vavilov VN, Zubarovskaya LS, Afanasyev BV. Time- and sample-dependent differences in polyomavirus incidence following hematopoietic stem cell transplantation. Cell Ther Transplant. 2016; 5(1): 26-30.

9. Chukhlovin A, Ovsyannikova M, Semenova E, Pankratova O, Zubarovskaya L, Afanasyev B Incidence of herpesvirus activation in young HSCT patients. 33 EBMT Meeting, Lyon, France, 2007. Abstr. P719.

10. Cohen JI, Bollard CM, Khanna R, Pittaluga S. Current understanding of the role of Epstein-Barr virus (EBV) in lymphomagenesis and therapeutic approaches to EBV associated lymphomas. Leuk Lymphoma 2008;49(Suppl 1):27-34.

11. Dean HF, Cazaly A, Hurlock C, Borras J, Williams AP, Johnson PW, Davies AJ. Defects in lymphocyte subsets and serological memory persist a median of 10 years after high-dose therapy and autologous progenitor cell rescue for malignant lymphoma. Bone Marrow Transplant. 2012;47(12):1545-1551.

12. de Koning C, Plantinga M, Besseling P, Boelens JJ, Nierkens S. Immune reconstitution after allogeneic hematopoietic cell transplantation in children. Biol Blood Marrow Transplant. 2016; 22(2):195-206.

13. Gerritsen EJ, van Tol MJ, Lankester AC, van der Weijden-Ragas CP, Jol-van der Zijde CM, Oudeman-Gruber NJ, Radl J, Vossen JM. Immunoglobulin levels and monoclonal gammopathies in children after bone marrow transplantation. Blood 1993; 82:3493-3502

14. Gismondi A, Stabile H, Nisti P, Santoni A. Effector functions of natural killer cell subsets in the control of hematological malignancies. Front. Immunol. 6:567. doi: 10.3389/ fimmu.2015.00567

15. Gratama JW, Naipal A, Oljans P, Zwaan FE, Verdonck LF, de Witte T, Vossen JM, Bolhuis RL, de Gast GC, Jansen J. T lymphocyte repopulation and differentiation after bone marrow transplantation. Early shifts in the ratio between T4+ and T8+ T lymphocytes correlate with the occurrence of acute graft-versus-host disease. Blood 1984;63:1416-1423.

16. Gress RE, Emerson SG, Drobyski WR. Immune reconstitution: how it should work, what's broken, and why it matters. Biol Blood Marrow Transplant. 2010; 16(1 Suppl):S133-137.

17. Hakim FT, Cepeda R, Kaimei S, Mackall CL, McAtee N, Zujewski J, Cowan K, Gress RE. Constraints on CD4 recov- ery postchemotherapy in adults: Thymic insufficiency and apoptotic decline of expanded peripheral CD4 cells. Blood 1997;90 (9): 3789-3798

18. Hakim FT, Memon SA, Cepeda R, Jones EC, Chow CK, Kasten-Sportes C, Odom J, Vance BA, Christensen BL, Mackall CL, Gress RE. Age-dependent incidence, time course, and consequences of thymic renewal in adults. J Clin Invest 2005;115(4):930-939

19. Junghanss C, Boeckh M, Carter RA, Sandmaier BM, Maris MB, Maloney DG, Chauncey T, McSweeney PA, Little MT, Corey L, Storb R. Incidence and outcome of cytomegalovirus infections following nonmyeloablative compared with myeloablative allogeneic stem cell transplantation, a matched control study. Blood. 2002;99(6):1978-1985.

20. Inaba H, Hartford CM, Pei D, Posner MJ, Yang J, Hayden RT, Srinivasan A, Triplett BM, McCulllers JA, Pui CH, Leung W. Longitudinal analysis of antibody response to immunization in paediatric survivors after allogeneic haematopoietic stem cell transplantation. Br J Haematol. 2012;156(1):109117.

21. Klyuchnikov E, Asenova S, Kern W, Kilinc G, Ayuk F, Wiedemann B, Lioznov M, Freiberger P, Zalyalov Y, Zander AR, Kröger N, Bacher U. Post-transplant immune reconstitution after unrelated allogeneic stem cell transplant in patients with acute myeloid leukemia.Leuk Lymphoma. 2010;51(8):1450-1463.

22. Koehne G, Zeller W, Stockschlaeder M, Zander AR. Phenotype of lymphocyte subsets after autologous peripheral blood stem cell transplantation. Bone Marrow Transplant. 1997;19(2):149-156.

23. Lindemann M, Barsegian V, Runde V, Fiedler M, Heermann KH, Schaefer UW, Roggendorf M, Grosse-Wilde H. Transfer of humoral and cellular hepatitis B immunity by allogeneic hematopoietic cell transplantation. Transplantation. $2003 ; 75(6): 833-838$.

24. Ljungman P, Avetisyan G. Influenza vaccination in hematopoietic SCT recipients. Bone Marrow Transplant. 2008; 42(10): 637-641.

25. Ljungman P. The role of cytomegalovirus serostatus on outcome of hematopoietic stem cell transplantation. Curr Opin Hematol. 2014 Nov;21(6):466-9.

26. Longnecker R., Neipel F. Introduction to the human gamma-herpesviruses. In: Human Herpesviruses: Biology, Therapy, and Immunoprophylaxis (Ed. A. Arvin, G. Campadelli-Fiume et al.). Cambridge University Press, 2007, Chapter 22.

27. Lucas KG, Small TN, Heller G, Dupont B, O’Reilly RJ. The development of cellular immunity to Epstein-Barr virus after allogeneic bone marrow transplantation. Blood 1996;87:2594-2603.

28. Ludwig B, Kraus FB, Kipp M, Preiser W, Schwerdtfeger R, Doerr HW, Buxbaum S. Cytomegalovirus-specific CD4 T-cell and glycoprotein B specific antibody response in recipients of allogenic stem cell transplantation. J Clin Virol. 2006; 35(2): 160-166. 
29. Lum LG, Seigneuret MC, Orcutt-Thordarson N, Noges JE, Storb R. The regulation of immunoglobulin synthesis after HLA-identical bone marrow transplantation: VI. Differential rates of maturation of distinct functional groups within lymphoid subpopulations in patients after human marrow grafting. Blood. 1985;65(6):1422-1433.

30. Mackall CL, Fleisher TA, Brown MR, et al. Age, thymopoiesis, and $\mathrm{CD} 4+\mathrm{T}$-lymphocyte regeneration after intensive chemotherapy. New Engl J Med 1995; 332(3):143-149.

31. Maeda Y, Teshima T, Yamada M, Shinagawa K, Nakao S, Ohno Y, Kojima K, Hara M, Nagafuji K, Hayashi S, Fukuda S, Sawada H, Matsue K, Takenaka K, Ishimaru F, Ikeda K, Niiya K, Harada M. Monitoring of human herpesviruses after allogeneic peripheral blood stem cell transplantation and bone marrow transplantation. Br J Haematol. 1999; 105(1):295-302.

32. Moosmann A, Hammerschmidt W, Kolb HJ. Virus-specific $\mathrm{T}$ cells for therapy--approaches, problems, solutions. Eur J Cell Biol. 2012;91(1):97-101.

33. Muñoz I, Gutiérrez A, Gimeno C, Farga A, Alberola J, Solano C, Prósper F, García-Conde J, Navarro D. Lack of association between the kinetics of human cytomegalovirus (HCMV) glycoprotein B (gB)-specific and neutralizing serum antibodies and development or recovery from HCMV active infection in patients undergoing allogeneic stem cell transplant. J Med Virol. 2001; 65(1): 77-84.

34. Nakamae H, Kirby KA, Sandmaier BM, Norasetthada L, Maloney DG, Maris MB, Davis C, Corey L, Storb R, Boeckh M. Effect of Conditioning Regimen Intensity on CMV Infection in Allogeneic Hematopoietic Cell Transplantation. Biol Blood Marrow Transplant. 2009; 15(6): 694-703.

35. Nguyen S, Dhedin N, Vernant JP, Kuentz M, AlJijakli A, Rouas-Freiss N, et al. NK-cell reconstitution after haploidentical hematopoietic stem-cell transplantations: immaturity of NK cells and inhibitory effect of NKG2A override GvL effect. Blood 2005; 105:4135-4142.

36. Nourse JP, Jones K, Gandhi MH Epstein-Barr-virus-related post-transplant lymphoproliferative disorders: pathogenetic insights for targeted therapy. Am J Transpl 2011; 11(5): 888-895.

37. Pankratova OS, Chukhlovin AB, Zubarovskaya LS, Afanasyev BV. Incidence of herpesvirus detection and risk of common complications in allogeneic hematopoietic stem cell transplantation. Scientific Notes of the St.Petersburg State Medical University 2010; 17(1):56-60. (In Russian)

38. Pankratova OS, Chukhlovin AB, Shiryaev SN, Eismont YA, Vavilov VN, Zubarovskaya LS, Afanasyev BV. Herpesviruses and oral ulcerations in hematopoietic SCT recipients. Bone Marrow Transplant. 2013; 48(10):1364-1365.

39. Pechumer H, Leinisch E, Bender-Götze C, Ziegler-Heitbrock HW. Recovery of monocytes after bone marrow transplantation rapid reappearance of tumor necrosis factor alpha and interleukin 6 production. Transplantation. 1991; 52(4): 698-704.

40. Roy DM, Brenner MK, Cook D, Duncan RI, Griffiths PD,
Grundy JE. Transfer of humoral immunity against cytomegalovirus proteins following transplantation of T-cell-depleted allogeneic bone marrow from seropositive donors. J Med Virol. 1993; 41(2): 150-158.

41. Ruell J, Barnes C, Mutton K, Foulkes B, Chang J, Cavet J, Guiver M, Menasce L, Dougal M, Chopra R. Active CMV disease does not always correlate with viral load detection. Bone Marrow Transplantation. 2007; 40: 55-61.

42. Sahdev I, O’Reilly R, Black P, Heller G, HoffmannM. Interleukin-1 production following T-cell-depleted and unmodified marrow grafts. Pediatr Hematol Oncol 1996; 13:55-67.

43. Schaenman JM, Shashidhar S, Rhee C, Wong J, Navato S, Wong RM, Ho DY, Arai S, Johnston L, Brown JM. Early CMV viremia is associated with impaired viral control following nonmyeloablative hematopoietic cell transplantation with a total lymphoid irradiation and antithymocyte globulin preparative regimen. Biol Blood Marrow Transplant 2011;17:693-702.

44. Seggewiss R, Einsele H. Immune reconstitution after allogeneic transplantation and expanding options for immunomodulation: an update. Blood. 2010; 115(19): 3861-3868.

45. Snow AL, Martinez OM. Epstein-Barr virus: evasive maneuvers in the development of PTLD. Am J Transplant 2007; 7(2):271-277.

46. Storek J, Joseph A, Espino G, Dawson MA, Douek DC, Sullivan KM, Flowers ME, Martin P, Mathioudakis G, Nash RA, Storb R, Appelbaum FR, Maloney DG. Immunity of patients surviving 20 to 30 years after allogeneic or syngeneic bone marrow transplantation. Blood 2001; 98:3505-3512.

47. Storek J, Geddes M, Khan F, Huard B, Helg C, Chalandon Y, Passweg J, Roosnek E. Reconstitution of the immune system after hematopoietic stem cell transplantation in humans. Semin Immunopathol. 2008; 30(4): 425-437.

48. Tischer J, Engel N, Fritsch S, Prevalsek D, Hubmann M, Schulz C, Zoellner AK, Bücklein V, Reibke R, Mumm F, Rieger CT, Hill W, Ledderose G, Stemmler HJ, Köhnke T, Jäger G, Kolb HJ, Schmid C, Moosmann A, Hausmann A. Virus infection in HLA-haploidentical hematopoietic stem cell transplantation: incidence in the context of immune recovery in two different transplantation settings. Ann Hematol. 2015;94(10):1677-1688.

49. Travi G, Pergam SA. Cytomegalovirus pneumonia in hematopoietic stem cell recipients. J Intensive Care Med. 2014; 29(4):200-212.

50. Tzannou I, Leen AM. Accelerating immune reconstitution after hematopoietic stem cell transplantation. Clin Transl Immunology. 2014; 3(2):e11. doi: 10.1038/cti.2014.2. eCollection 2014.

51. Vago L, Forno B, Sormani MP, Crocchiolo R, Zino E, DiTerlizzi S, etal. Temporal, quantitative, and functional characteristics of single-KIR-positive alloreactive natural killer cell recovery account for impaired graft-versus- leukemia activity after haploidentical hematopoietic stem cell transplantation. Blood. 2008; 112:3488-3499. 
52. van Tol MJ, Gerritsen EJ, de Lange GG, van Leeuwen AM, Jol-van der Zijde CM, Oudeman-Gruber NJ, de Vries E, Radl J, Vossen JM. The origin of IgG production and homogeneous IgG components after allogeneic bone marrow transplantation. Blood 1996; 87:818-826.

53. Wald A, Corey L. Human Herpesviruses: Biology, Therapy, and Immunoprophylaxis (ed. A. Arvin, G. Campadelli-Fiume et al.) Cambridge University Press. - 2007. - Chapter 36. URL: http://www.ncbi.nlm.nih.gov/books/NBK47376/

54. Zhou W, Longmate J, Lacey SF, Palmer JM, Gallez-Hawkins G, Thao L, Spielberger R, Nakamura R, Forman
SJ, Zaia JA, Diamond DJ. Impact of donor CMV status on viral infection and reconstitution of multifunction CMV-specific $\mathrm{T}$ cells in CMV-positive transplant recipients. Blood 2009;113(25):6465-6476.

55. Zimmerli W, Zarth A, Gratwohl A, Speck B. Neutrophil function and pyogenic infections in bone marrow transplant recipients. Blood 1991; 77:393-399.

56. Zucca E, Bertoni F, Vannata B, Cavalli F. Emerging role of infectious etiologies in the pathogenesis of marginal zone B-cell lymphomas. Clin Cancer Res. 2014; 20(20): 52075216. 


\title{
Временная динамика восстановления иммунитета и вирусная реактивация после трансплантации гемопоэтических стволовых клеток
}

\author{
Ольга С. Панкратова ${ }^{1}$, Алексей Б. Чухловин ${ }^{2}$ \\ ${ }^{1}$ Госпиталь Университета г. Тампере, Финляндия \\ ${ }^{2}$ НИИ детской онкологии, гематологии и трансплантологии им. Р. М. Горбачевой, Первый Санкт-Петербургский \\ государственный медицинский университет им. акад. И. П.Павлова, Санкт-Петербург, Россия
}

\section{Резюме}

Полное истощение клеточных популяций врожденного и адаптивного иммунитета возникает после интенсивной химиотерапии и трансплантации гемопоэтических стволовых клеток (ТГСК), за чем следует постепенное восстановление иммунной системы за счет предшественников, образующихся из донорских гемопоэтических клеток, которые дифференцируются в миелоидный и лимфоидные ростки. Временная динамика восстановления иммунной системы и, в частности, отдельных клеточных популяций изучена лишь отчасти, особенно в ранние сроки после ТГСК. Например, популяции клеток врожденного иммунитета восстанавливаются в течение 1-го месяца после ТГСК, в связи с быстрым обновлением популяций гранулоцитов, моноцитов и НК-клеток. В то же время функциональное созревание субпопуляций НК-клеток и моноцитов крови может длиться до 3 мес.

Как Т-, так и В-лимфоциты восстанавливаются гораздо медленнее, чем миеломоноцитарные популяции. Есть лишь ограниченная информация об их посттрансплантационном обновлении, так как большинство исследований проводились в поздние сроки (>1 мес. после ТГСК). Так, абсолютное число CD8+ Т-клеток нормализуется примерно через 4 мес., при суженном спектре Т-лимфоцитов памяти. Темпы восстановления и созревания $\mathrm{CD} 4+\mathrm{T}$ во многом зависят от остаточной функции тимуса, особенно в младших возрастах. Поэтому у младших пациентов преобладает популяция «наивных» $\mathrm{CD} 4+\mathrm{T}$ cell в сроки $>6$ мес. после ТГСК. У лиц старшего возраста с инактивацией функции тимуса общее число CD4 клеток остается низким годами после ТГСК. В то же время антивирусный клеточный иммунитет активен, начиная с ранних сроков после трансплантации. Так, цитотоксические CD8+ клетки, специфичные в отношении ЦМВ или ВЭБ, быстро размножаются в случаях реактивации этих вирусов после ТГСК.

Несмотря на восстановление абсолютных количеств В-клеток к 30-му дню после ТГСК, их функции (в т.ч. - антиген-специфическая продукция антител) снижены многие месяцы и годы после ТГСК из-за медленного восстановления зрелых популяций иммунных клеток, что напоминает постепенную эволюцию в иерархии В-клеток в организме человека.

Реактивация герпесвирусов (в основном -ЦМВ, ВЭБ и ВПГ) является известным признаком иммунодефицита. Периоды максимального риска реактивации герпесвирусов (2-3 мес. после ТГСК) соответствуют периодам функционального дефицита CD8+ и CD4+ Т-клеток, а также незрелости В-клеток, что отражает их недостаточную способность к устранению лейкоцитов, пораженных герпесвирусами. Индивидуальные сроки иммунного восстановления после ТГСК зависят от возраста больного, источника донорских клеток, развития острой РТПХ после трансплантации и др. Ответ на вакцинирование - важный критерии состояния иммунитета после ТГСК - также зависит от возраста больного и сохранности функций В-клеток. Временная динамика специфического антительного ответа показывает, что больные с латентной реактивацией ЦМВ могут позже проявить сильный гуморальный иммунитет, что ведет к ограничению инфекционного процесса.

\section{Ключевые слова}

Трансплантация гемопоэтических стволовых клеток, восстановление иммунитета, различия в созревании, временная динамика, герпесвирусы, реактивация 